\title{
Genetic diversity and population structure of endangered plant species Anagallis foemina Mill. [Lysimachia foemina (Mill.) U. Manns \& Anderb.]
}

\author{
Ewa Kwiecińska-Poppe ${ }^{1}$ (D) Małgorzata Haliniarz $^{1}$ (D) $\cdot$ Sylwia Sowa $^{2}$ (D) \\ Edyta Paczos-Grzęda ${ }^{2}$ (1)
}

Received: 20 March 2020/Revised: 5 June 2020/Accepted: 12 June 2020/Published online: 7 July 2020

(C) The Author(s) 2020

\begin{abstract}
Anagallis foemina L. [syn. Lysimachia foemina (Mill.) U. Manns \& Anderb.] is an annual, segetal weed from the family Primulaceae, recognized as a very rare and endangered species in many European countries. The rare occurrence of this species is associated with the specificity of the habitats in which it occurs. Knowledge of genetic diversity within and between rare species populations is a crucial step for investigating the causes of extinction as well as developing effective conservation strategies. The current study undertakes the assessment of the genetic variation and population structure of Anagallis foemina $\mathrm{L}$. specimens collected in south-eastern Poland, Volhynian Polesie and West Volhynian Upland based on inter-simple sequence repeats (ISSR) polymorphism. Twenty ISSR primers amplified 374 DNA fragments, of which $79 \%$ were polymorphic. The polymorphic information content values ranged from 0.230 to 0.430 with an average of 0.344 . An average genetic similarity calculated based on Dice algorithm between all analysed samples was $0.635(0.28-1.00)$. The AMOVA study found a significant difference $\left(\Phi_{\mathrm{pt}-}\right.$ $=0.88, P=0.001$ ) between Anagallis L. genotypes gathered in Volhynian Polesie (VP) and West Volhynian Upland (VU). Analysis indicated, that $89 \%$ of the variation existed among groups and $11 \%$ within groups. UPGMA analyses grouped A. foemina samples into 2 clearly separated clusters. The plants of the same geographic origin were grouped together. Principal coordinates analysis
\end{abstract}

Edyta Paczos-Grzęda

edyta.paczos@up.lublin.pl

1 Department of Herbology and Plant Cultivation Techniques, University of Life Sciences in Lublin, Lublin, Poland

2 Institute of Plant Genetics, Breeding and Biotechnology, University of Life Sciences in Lublin, Lublin, Poland
(PCoA) as well as STRUCTURE also grouped samples in consistence with the collection site, indicating close genetic affinity of plants from the same location. The observed results are typical for fragmented and isolated populations of rare species. Isolation of a small population leads to a decrease in internal genetic variation and to an increase of variation among them. In that case, the conservation of populations from each regional cluster is important to preserve biodiversity.

Keywords Genetic similarity · ISSR - Molecular markers · Primulaceae

\section{Introduction}

According to the taxonomy established by Pax and Knuth (1905) and modified by Hu (1994), Källersjö et al. (2000), Stahl and Anderberg (2004), tribe Lysimachieae (Рrimulaceae) included six genera: Lysimachia, Anagallis, Trientalis, Glaux, Asterolinon, and Pelletiera. However, based on cpDNA as well as rDNA sequence studies (Banfi et al. 2005; Manns and Anderberg 2005, 2007a, 2009; Yan et al. 2018), this traditional classification has been changed and all genera merged into Lysimachia. Currently, Anagallis is accordingly treated as a group nested within Lysimachia L. genus (Källersjö et al. 2000) placed in Primulaceae (China Phylogeny Consortium 2016).

Anagallis group comprises 31 species of small herbs with pink, white, and sometimes red or blue flowers, with a majority narrowly distributed in tropical areas. Only a few species (i.a. A. monelli or A. foemina) occur in Mediterranean region or in Europe, including A. arvensis, a weed that has a more widespread global distribution (Anderberg and Ståhl 1995). 
In Poland, there are two species of Anagallis, A. arvensis [syn. Lysimachia arvensis (L.) U. Manns \& Anderb.] and $A$. foemina [syn. Lysimachia foemina (Mill.) U. Manns \& Anderb]. The first is common in segetal and ruderal communities throughout the country and increases in numbers (Kornaś 1962; Staniak et al. 2017). The other, A. foemina, is a species, which sporadically and only locally occurs in agrophytocoenoses or in uncultivated areas on calcareous soils (Fijałkowski 1978; Haliniarz and Kapeluszny 2014).

A. foemina is an archeophyte which was introduced to Poland before the end of the 15th century (Fijałkowski 1978). This species grows mainly in extensive cereal or root crops (Kornaś 1962), less often on roadside and rubble (Fijałkowski 1978). The rare occurrence of $A$. foemina is associated with the specificity of the habitats in which it occurs. It is found in sunny, warm and dry places (Kornaś 1962). It grows on calcium rich soils, most often on relatively dry heavy chalky rendzinas produced on chalk marls and tertiary gypsum sediments (Fijałkowski 1978). The number of $A$. foemina populations is constantly decreasing (Siciński and Sieradzki 2010) and is reported as a species at risk of extinction in many European countries (Brütting 2013; Kolárová et al. 2013). The species was placed on the national red list of Polish plants and fungi in the category of endangered species (Kaźmierczakowa et al. 2016). On the Volhynian Polesie and West Volhynian Upland according to Kucharczyk (2004), A. foemina belongs to critically endangered species, but based on Haliniarz and Kapeluszny (2014) as well as Cwener et al. (2016) studies, this species is exposed to extinction.

Thus far, molecular analysis of A. foemina concerned mainly of intrageneric relationships assessment within Anagallis, based on rDNA or cpDNA sequence polymorphisms, so were concentrated on the restricted parts of a genome (Banfi et al. 2005; Manns and Anderberg 2007b, 2009; Yan et al. 2018). The aim of our study was primarily to investigate the genetic diversity within endangered species A. foemina using samples collected in south-eastern Poland employing ISSR (inter simple sequence repeats) method developed to identify DNA polymorphism in the proximity of microsatellites. Invaluable information on the basis of this studies regarding endangered species protection, not only in Poland, but also in European countries is expected.

\section{Materials and methods}

\section{Plant material}

Anagallis foemina Mill. [synonyms: Anagallis femina Will., Anagallis coerulea Schreb., Anagallis arvensis subsp. caerulea (Schreb.), Lysimachia foemina (Mill.) U.
Table 1 Geographical origin of Anagallis L. genotypes used in the study

\begin{tabular}{llll}
\hline Sample & \multicolumn{2}{l}{ Geographical coordinates } & Geographical region \\
\cline { 2 - 3 } & Latitude & Longitude & \\
\hline VU/1 & 51.1822 & 23.3660 & West Volhynian Upland (VU) \\
VU/2 & 51.1517 & 23.5797 & \\
VU/3 & 51.1160 & 23.5310 & \\
VU/4 & 51.1145 & 23.5189 & \\
VU/5 & 51.1152 & 23.5302 & \\
VU/6 & 51.0983 & 23.4448 & \\
VU/7 & 51.0825 & 23.4273 & \\
VU/8 & 51.0585 & 23.3913 & \\
VU/9 & 50.9739 & 23.7020 & \\
VP/1 & 50.4312 & 23.4983 & Volhynian Polesie (VP) \\
VP/2 & 50.4312 & 23.5191 & \\
VP/3 & 50.4100 & 23.5405 & \\
VP/4 & 50.4033 & 23.5445 & \\
VP/5 & 50.3677 & 23.5867 & \\
VP/5_r & 50.3677 & 23.5867 & \\
\hline
\end{tabular}

Manns \& Anderb] is a species with an erect, branched stem, growing up to $20 \mathrm{~cm}$ tall. Its dark green leaves, 5-20 mm long, are narrow-ovate, margin usually without glands, pointed. The upper leaves are often narrower than the lower ones and placed opposite on the stem. The flowers are $8 \mathrm{~mm}$ in diameter, five-petal, blue, red at the base. The petals of the crown do not overlap each other deeply, they have a few, non-glandular cilia $6 \times 3.5 \mathrm{~mm}$. Flower stalks are set individually in the leaf axils, during flowering, they are shorter or as long as the supporting leaves. It blooms and produces seeds from May to October. The fruit is a spherical, multi-seed bag (Rutkowski 2006). The number of $A$. foemina chromosomes is usually $2 \mathrm{n}=40$, but polyploidy is thought to be present in some populations (Clapham et al. 1987). It is an insect-pollinated and self-pollinating species. Its fertility is estimated at 200-300 seeds per plant, while the mass of a thousand seeds ranges from 0.6 to $0.7 \mathrm{~g}$ (Brütting 2013; Brütting et al. 2012a, b).

Plant material for genetic analyses was acquired in the years 2014-2016 (from June to July) from sites located in the fields of south-eastern Poland (Table 1, Fig. 1). Plants were collected from segetal communities, such as: winter wheat, spring wheat, spring barley, winter triticale, and sugar beet. A total of 14 Anagallis foemina L. samples as well as one Anagallis arvensis L. (as an outgroup for genetic analysis) were collected. Species affiliation was made through general characters for the species and the location. From each site, leaves were picked from 5 


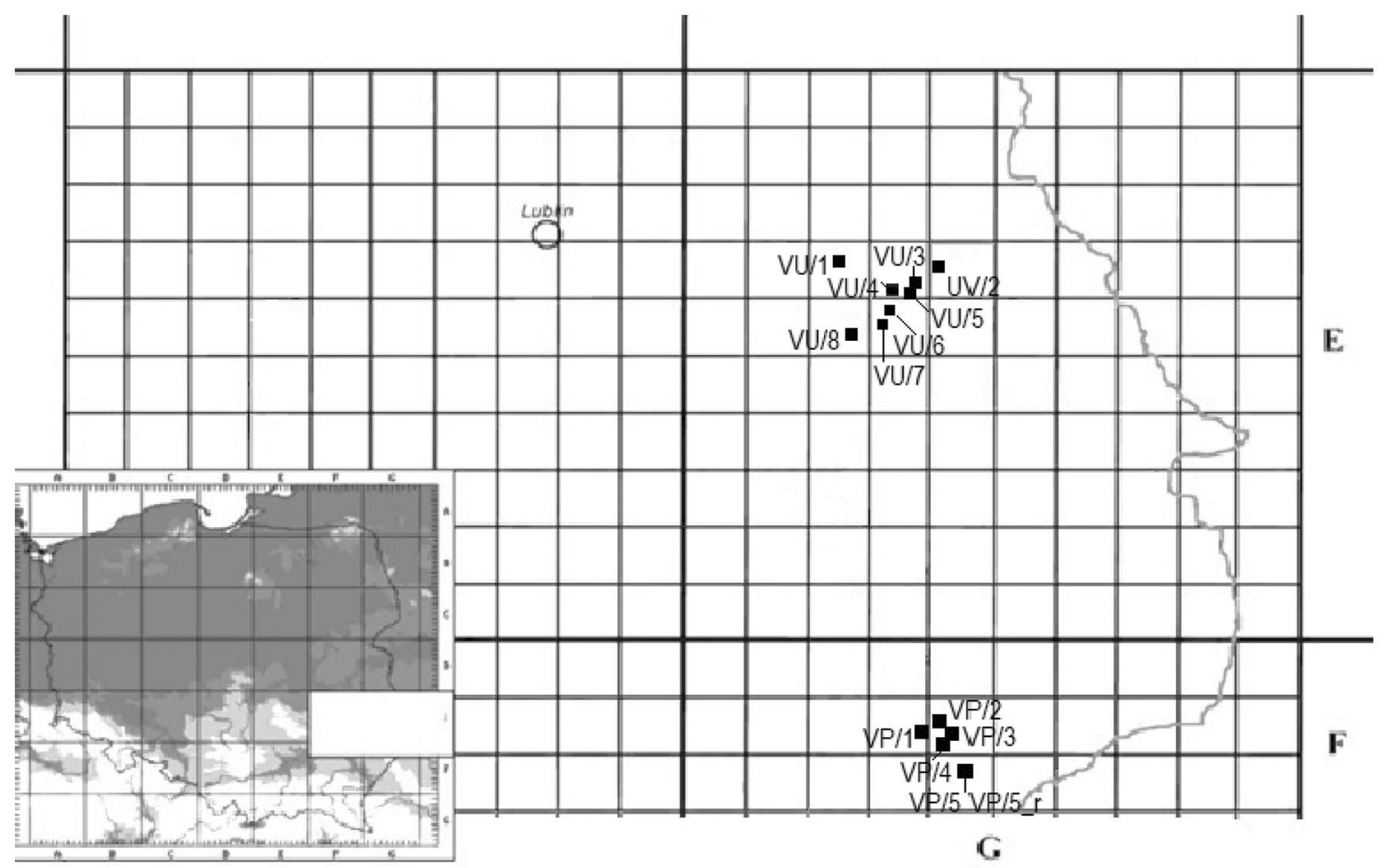

Fig. 1 Geographical distribution of collection sites of Anagallis foemina Mill. in south-eastern Poland

randomly selected plants. The exact geographical position of the sites was determined using a GPS device (Table 1).

Total genomic DNA was extracted from the leaf tissue of material frozen in liquid nitrogen using GeneMATRIX Plant \& Fungi DNA Purification Kit (EURx) and purified with Anti-Inhibitor Kit (A\&A Biotechnology). DNA integrity and quality were evaluated by electrophoresis on $1.5 \%$ agarose gel. The DNA concentration was determined with NanoDrop2000 spectrophotometry and normalized to $100 \mathrm{ng} / \mu \mathrm{L}$.

\section{Genotyping}

PCR reactions were carried out in a $12 \mu \mathrm{L}$ volume of a mixture containing $20 \mathrm{ng}$ of template DNA, $1 \times$ PCR Master Mix buffer $(0.05 \mathrm{U} / \mu \mathrm{L}$ Taq DNA polymerase, $4 \mathrm{mM} \mathrm{MgCl}_{2}, 0.4 \mathrm{mM}$ of each dNTP) (Thermo Fisher Scientific) and $0.6 \mathrm{nM}$ of primer (Table 2). The amplification protocol was performed according to the ISSR (Inter Simple Sequence Repeat) method, described by Zietkiewicz et al. (1994). Following temperature profile was used: $95{ }^{\circ} \mathrm{C}$ for $7 \mathrm{~min}$ (pre-denaturation); 3 cycles of $95{ }^{\circ} \mathrm{C}$ for $30 \mathrm{~s}, 54{ }^{\circ} \mathrm{C}$ for $45 \mathrm{~s}$, and $72{ }^{\circ} \mathrm{C}$ for $2 \mathrm{~min} ; 3$ cycles of $95{ }^{\circ} \mathrm{C}$ for $30 \mathrm{~s}, 53{ }^{\circ} \mathrm{C}$ for $45 \mathrm{~s}$, and $72{ }^{\circ} \mathrm{C}$ for $2 \mathrm{~min} ; 32$ cycles of $95{ }^{\circ} \mathrm{C}$ for $30 \mathrm{~s}, 52{ }^{\circ} \mathrm{C}$ for $45 \mathrm{~s}$, and $72{ }^{\circ} \mathrm{C}$ for $2 \mathrm{~min}$; and a final extension of $72{ }^{\circ} \mathrm{C}$ for $7 \mathrm{~min}$.

PCR products were separated on $1.5 \%$ agarose gel containing $5 \mu \mathrm{g} / \mathrm{ml} \mathrm{EtBr}$ in 1/TBE Buffer (90 mM Tris-
Table 2 List of ISSR primers used in the study and values of markers polymorphism indices: TNF total number of fragments, NPF number of polymorphic fragments, PPF percentage of polymorphic fragments and PIC polymorphism information content

\begin{tabular}{llrrrr}
\hline Name & Sequence $5^{\prime} \rightarrow 3^{\prime}$ & TNF & NPF & PPF $(\%)$ & PIC \\
\hline sr16 & $(\mathrm{GA})_{8} \mathrm{C}$ & 18 & 11 & 61 & 0.281 \\
sr17 & $(\mathrm{GA})_{8} \mathrm{YC}$ & 13 & 10 & 77 & 0.353 \\
sr28 & $(\mathrm{TG})_{8} \mathrm{G}$ & 23 & 22 & 96 & 0.422 \\
sr31 & $(\mathrm{AG})_{8} \mathrm{YC}$ & 29 & 22 & 76 & 0.348 \\
sr32 & $(\mathrm{AG})_{8} \mathrm{YT}$ & 21 & 15 & 71 & 0.328 \\
sr33 & $(\mathrm{AG})_{8} \mathrm{~T}$ & 13 & 8 & 62 & 0.283 \\
sr34 & $(\mathrm{TC})_{8} \mathrm{CC}$ & 11 & 8 & 73 & 0.334 \\
sr35 & $(\mathrm{TC})_{8} \mathrm{CG}$ & 30 & 29 & 97 & 0.403 \\
sr36 & $(\mathrm{AC})_{8} \mathrm{CG}$ & 9 & 8 & 89 & 0.408 \\
sr37 & $(\mathrm{AC})_{8} \mathrm{C}$ & 24 & 20 & 83 & 0.343 \\
sr39 & $(\mathrm{GA})_{8} \mathrm{GG}$ & 18 & 14 & 78 & 0.357 \\
sr40 & $(\mathrm{AC})_{8} \mathrm{~T}$ & 24 & 19 & 79 & 0.336 \\
sr41 & $(\mathrm{AG})_{10} \mathrm{C}$ & 29 & 25 & 86 & 0.366 \\
sr42 & $(\mathrm{AG})_{8} \mathrm{YA}$ & 25 & 25 & 100 & 0.430 \\
sr50 & $(\mathrm{TC})_{9} \mathrm{C}$ & 14 & 12 & 86 & 0.394 \\
sr53 & $(\mathrm{CT})_{8} \mathrm{~A}$ & 12 & 9 & 75 & 0.344 \\
sr55 & $(\mathrm{CAC})_{6} \mathrm{~A}$ & 13 & 10 & 77 & 0.353 \\
sr56 & $(\mathrm{CAC})_{6} \mathrm{G}$ & 12 & 6 & 50 & 0.230 \\
sr58 & $(\mathrm{ACC})_{6} \mathrm{~T}$ & 19 & 10 & 53 & 0.242 \\
sr60 & $(\mathrm{CAC})_{7} \mathrm{~T}$ & 17 & 12 & 71 & 0.324 \\
Mean & & 19 & 15 & 79 & 0.344 \\
\hline & & & & &
\end{tabular}


borate, $2 \mathrm{mM}$ EDTA, pH 8.0). To establish molecular weight of amplification products, Gene Ruler ${ }^{\mathrm{TM}} 100 \mathrm{bp}$ Plus DNA Ladder was used. Fragments were visualized under UV transilluminator and photographed.

\section{Molecular data analysis}

ISSR results were transformed into binary character matrix in the MS Excel by coding the presence of the clear band as 1 and its absence as 0. Marker informativeness was calculated for each primer by counting TNF-total number of fragments, NPF-number of polymorphic fragments and PPF-percentage of polymorphic fragments. PIC value (Polymorphism Information Content) was calculated according to Roldán-Ruiz et al. (2000a, b) as a mean of all PIC values for all amplified fragments using the formula:

$\mathrm{PIC}=2 * f_{i} *\left(1-f_{i}\right)$

$\mathrm{f}_{\mathrm{i}}$ frequency of the amplified allele (band present)

$\left(1-f_{i}\right)$ frequency of the null allele (band absent)

The genetic distance between studied genotypes was calculated based on Nei's formula (Nei and Li 1979). The geographic distance was calculated based on geographic coordinates of collection sites. The Mantel test (Smouse et al. 1986) with 999 permutations was conducted to seek the relationship between geographic and genetic distance. Unbiased expected heterozygosity $(\mathrm{He})$, percentage of polymorphic products as well as private bands were estimated by GenAlex 6.502 (Peakall and Smouse 2012). Analysis of Molecular Variance within and between groups of individuals divided based on the place of gathering, was determined by 999 permutations.

Relationships among all examined genotypes was estimated using the Dice algorithm (1945) and cluster analysis were performed using UPGMA (Unweighted Pair Group Method with Arithmetic Mean) with 1000 bootstraps, as well as PCoA (Principal Coordinate Analysis) in PAST 3.25 (Hammer et al. 2001).

The population structure was investigated using a Bayesian approach in the program STRUCTURE 2.3.4 (Porras-Hurtado et al. 2013). The admixture model (assuming that individuals may have part of the genome from each of the K populations) and correlated allele frequencies between populations were chosen. Run length was given 10,000 burn-ins followed by 100000 Markov Chain Monte Carlo replications. The number of clusters $(\mathrm{K})$ were set from 2 to 5 , each $\mathrm{K}$ value was run ten times. To select and visualize the optimal number of clusters, web-based software, StructureSelector ( $\mathrm{Li}$ and Liu 2018) integrating Clumpak program (Kopelman et al. 2015) was used.
Table 3 Dice genetic similarity of Anagallis L. genotypes collected in Volhynian Polesie (VP) and West Volhynian Upland (VU), based on ISSR data

\begin{tabular}{lll}
\hline Group & $\begin{array}{l}\text { West Volhynian } \\
\text { Upland (group 1) }\end{array}$ & $\begin{array}{l}\text { Volhynian Polesie } \\
\text { (group 2) }\end{array}$ \\
\hline $\begin{array}{l}\text { West Volhynian } \\
\text { Upland (group 1) }\end{array}$ & 0.904 & - \\
$\begin{array}{c}\text { Volhynian Polesie } \\
\text { (group 2) }\end{array}$ & 0.418 & 1 \\
Anagallis arvensis L. & 0.435 & 0.283 \\
\hline
\end{tabular}

\section{Results}

20 ISSR primers amplified 374 DNA fragments, of which 297 (79\%) were polymorphic. In average, a single primer initialized synthesis of 19 fragments (range 9-30). ISSR primer sr35 triggered amplification of the highest number of polymorphic bands (30), whereas sr36-the lowest (9). The rates of informative polymorphic bands varied from $50 \%$ (sr56) to $100 \%$ (sr42). PIC score ranged from 0.230 (sr56) to 0.430 (sr42) with an average of 0.344 (Table 2).

An average genetic similarity calculated based on Dice algorithm between all analysed samples was 0.635 (0.28-1.00) (data not shown). Genetic similarity indices estimated within Volhynian Polesie (VP) and West Volhynian Upland samples were very high and reached 1.000 and 0.904 , respectively (Table 3 ). The similarity between specimens collected at VP and VU was 0.418 and was nearly the same as genetic similarity of VU samples to $A$. arvensis (0.435). Simultaneously, Dice index value between A. foemina from Volhynian Polesie and A. arvensis reached 0.283 . Pairwise Mantel test showed statistically significant correlation between geographic and genetic distance of all analysed genotypes $(0.955$, $P=0.01$.

The AMOVA study found a significant difference $\left(\Phi_{\mathrm{pt}}=0.88, P=0.001\right)$ between Anagallis L. genotypes gathered in Volhynian Polesie (VP) and West Volhynian Upland (VU), Poland. Analysis indicated, that $89 \%$ of the variation existed among groups and $11 \%$ within groups.

Percentage of polymorphic loci of about $23.8 \%$ was observed for Anagallis from West Volhynian Upland (VU). Number of private bands for this group was 163. Much lower value $(0.08 \%)$ was observed for Anagallis from Volhynian Polesie. There were 105 bands unique to this group of genotypes (Table 4). Average unbiased expected heterozygosity ( $\mathrm{uHe}$ ) of genotypes groups was 0.091 .

A single A. arvensis genotype was attached to the analysis to verify species affiliation of remaining study objects. UPGMA analyses based on all marker types, 
Table 4 The within-group genetic diversity of Anagallis foemina L. genotypes collected in Volhynian Polesie (VP) and West Volhynian Upland (VU), based on ISSR data

\begin{tabular}{|c|c|c|c|c|c|}
\hline Group & Origin & $\begin{array}{l}\text { No. of } \\
\text { bands }\end{array}$ & $\begin{array}{l}\text { Percentage of polymorphic loci } \\
(\%)\end{array}$ & $\begin{array}{l}\text { No. of private } \\
\text { bands }\end{array}$ & $\begin{array}{l}\text { Unbiased expected heterozygosity } \\
(\mathrm{uHe})\end{array}$ \\
\hline 1 & $\begin{array}{l}\text { West Volhynian } \\
\text { Upland }\end{array}$ & 269 & 23.8 & 163 & 0.089 \\
\hline 2 & Volhynian Polesie & 211 & 0.8 & 105 & 0.002 \\
\hline Mean & & 240 & 12.3 & 134 & 0.091 \\
\hline
\end{tabular}

No. Bands $=$ No. of different bands

No. Private Bands $=$ No. of bands unique to a single population

No. Bands Freq. $\geq 5 \%=$ No. of Different Bands with a Frequency $\geq 5 \%$

No. LComm Bands $(\leq 25 \%)=$ No. of Locally Common Bands (Freq. $\geq 5 \%$ ) Found in $25 \%$ or Fewer Group

No. LComm Bands $(\leq 50 \%)=$ No. of Locally Common Bands (Freq. $\geq 5 \%$ ) Found in $50 \%$ or Fewer Group

$\mathrm{uHe}=$ Unbiased Expected Heterozygosity $=(2 \mathrm{~N} /(2 \mathrm{~N}-1)) * \mathrm{He}$

grouped A. foemina samples into 2 clearly separated clusters (Fig. 2). The first is composed of all A. foemina genotypes collected in Volhynian Polesie (VP). Second cluster encompasses A. foemina from West Volhynian Upland (VU). Dendrogram shows that A. arvensis (VP_r) is distinct from both of these groups and is located separately. Principal coordinate analysis (Fig. 3) gives congruent results, confirming the cluster analyses. The two coordinates explain $95 \%$ of total variance.

To estimate genetic structure of Anagallis L. genotypes, STRUCTURE software was run for $\mathrm{K}=2-5$. The maximum $\Delta \mathrm{K}$ occurred at $\mathrm{K}=4$ and was 2.48150 (Fig. 4). At $\mathrm{K}=3, \Delta \mathrm{K}$ was equal 0.61182 . Remaining results were significantly lower. A. foemina collected in West Volhynian Upland (VU) represents first group, second group is composed of A. foemina from West Volhynian Upland (VU). A. arvensis is recognized as a distinct gene pool (Fig. 5).

\section{Discussion}

Intensification of farming, changes in cultivation techniques, widespread use of plant protection products, thorough cleaning of seeds for sowing and reduction of ruderal habitats area, caused changes in the structure of agrophytocenoses and have an impact on becoming of some weed species rare in plant cultivation (Baessler and Klotz 2006; Storkey et al. 2012; Meyer et al. 2013; Mayerová et al. 2018). Species associated with specific crops and with a narrow ecological amplitude are particularly sensitive to any fluctuations in habitat conditions (Haliniarz and Kapeluszny 2014; Staniak et al. 2017). Archeophytes, growing on heavy calcareous soils, which are species characteristic of the Lathyro-Melandrietum noctiflori, Caucalido-Scandicetum or Kickxietum spuriae complexes are rapidly decreasing from cultivated fields (Nowak et al. 2008). The annual form of weeds makes some species very sensitive to environmental changes and susceptible to population fragmentation (Brütting et al. 2012a, b). Increasingly smaller and fragmented populations of rare species are more sensitive to the threat of loss of genetic diversity, inbred depression or the accumulation of new harmful mutations (Frankham et al. 2002). It is therefore necessary to examine the genetic variability of the population of endangered species, which can be the basis for the development of programs of their protection (Parusel et al. 2009; Frankham 2010; Janiak et al. 2014.

The level of polymorphism revealed by ISSR approach was very high and reached $79 \%$. About 300 polymorphic loci have been identified within analysed materials. According to Nei and Li (1979), 50 differentiating loci are necessary to evaluate the genetic variability. Pejic et al. (1998) reported, that more than 150 markers were necessary to obtain a good precision in analysing genetic diversity, irrespectively of technique employed. Based on PIC values, it can be concluded that marker system capacity to detect polymorphic loci in a single amplification was very efficient as the average value of this coefficient amounted 0.344 . This results proved this technique can be conveniently used for the genetic characterization of Anagallis species.

Genetic similarity analysis based on Dice algorithm, as well as AMOVA study of A. foemina samples gathered from Volhynian Polesie (VP) and West Volhynian Upland (VU) revealed significant difference $\left(\Phi_{\mathrm{pt}}=0.88\right.$, $P=0.001)$ between genepools derived from these locations. Simultaneously, within groups variation was low (11\%) with genetic similarity from 0.904 to 1.000 . It indicates a very low diversity of populations, especially Volhynian Polesie derived, and can be an effect of population fragmentation as well as the genetic isolation. 
Fig. 2 UPGMA dendrogram of Anagallis L. genotypes collected in Volhynian Polesie (VP) and West Volhynian Upland (VU), based on Dice similarity index. Bootstrap value indicated on nodes. (_b -

A. foemina,_r - A. arvensis)
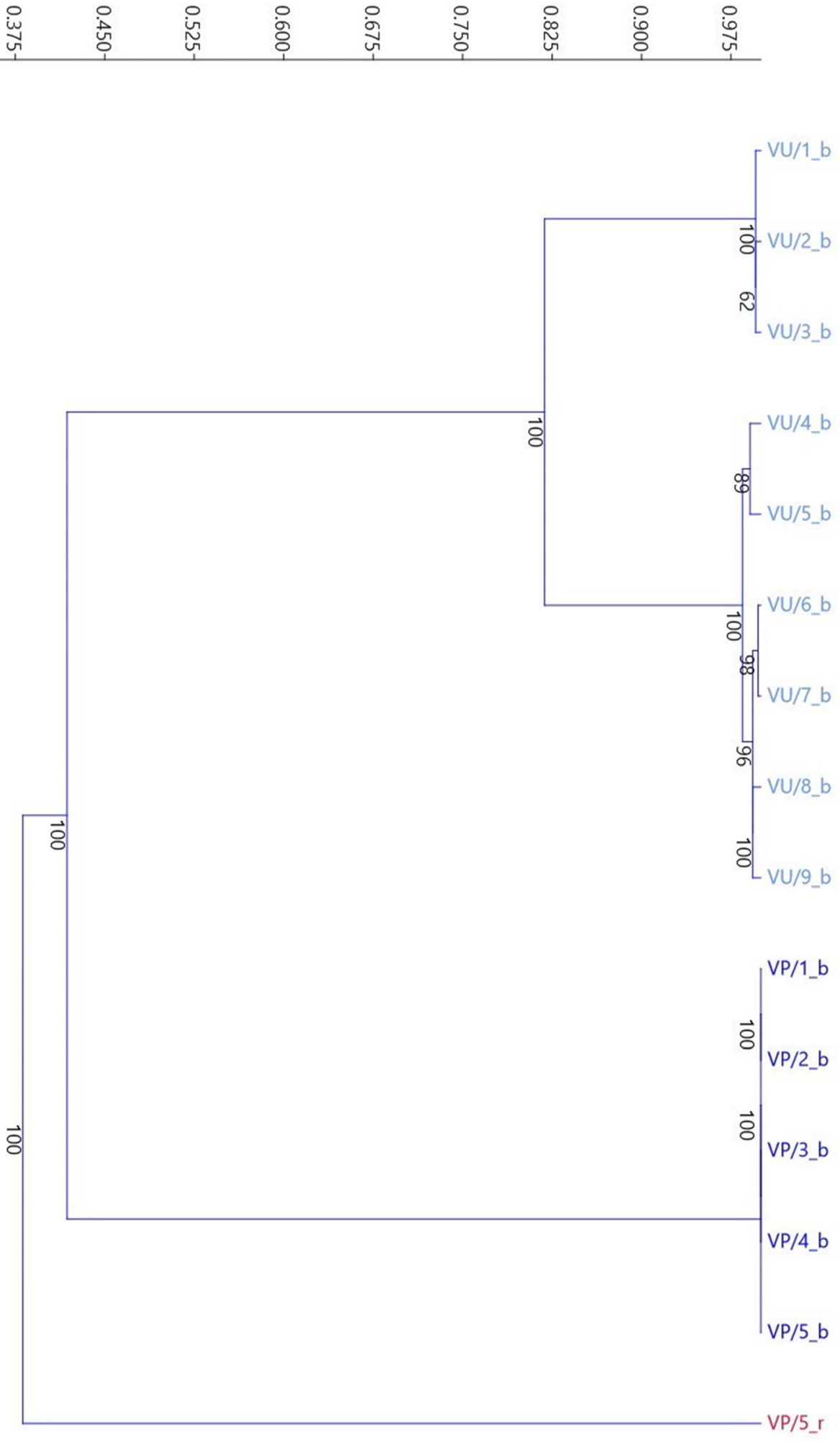

Consistent results were obtained by Brütting et al. (2013) who found that $A$. foemina within population diversity was on a very low level (16\%). Greater diversity of molecular variance was observed between the populations studied and this is also in agreement with our results. The strong differentiation of $A$. foemina populations between geographical regions indicates that current gene flow is very low. Daco et al. (2019) analyzing the protected species of 
Fig. 3 Principal coordinates 1 versus 2 plotted for Anagallis L. genotypes collected in

Volhynian Polesie (VP) and

West Volhynian Upland (VU), Poland, based on Dice similarity index

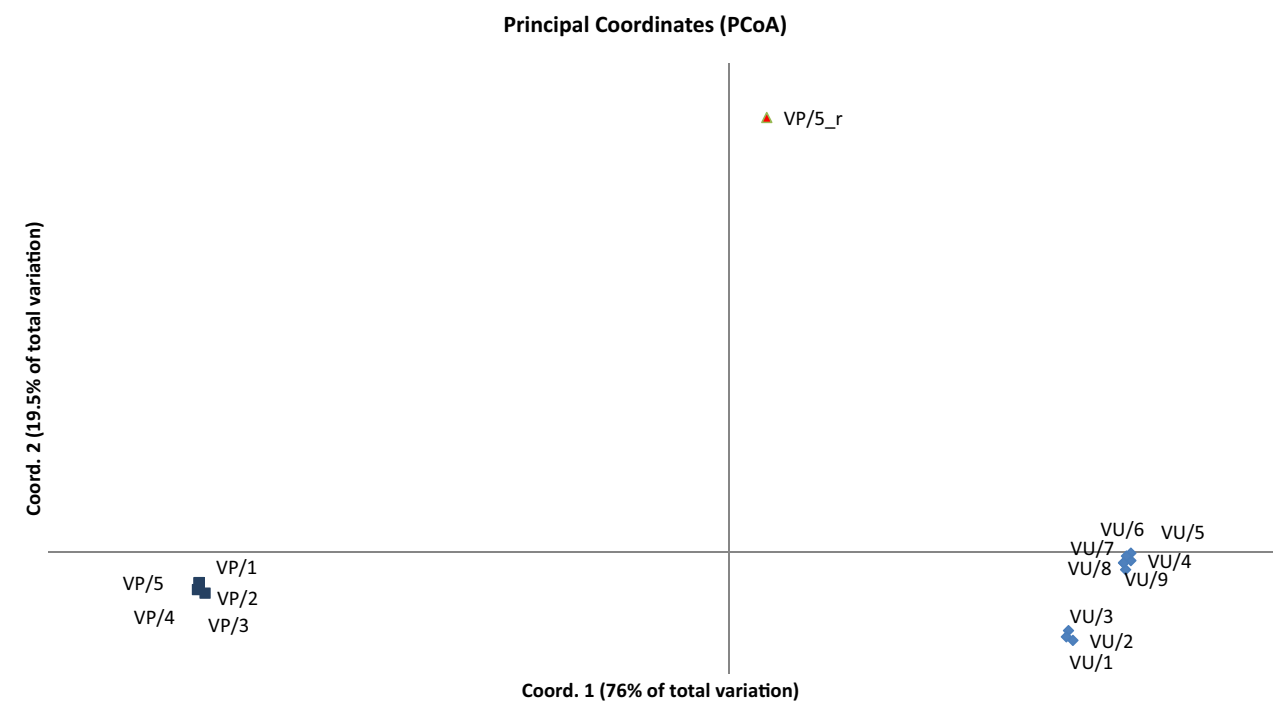

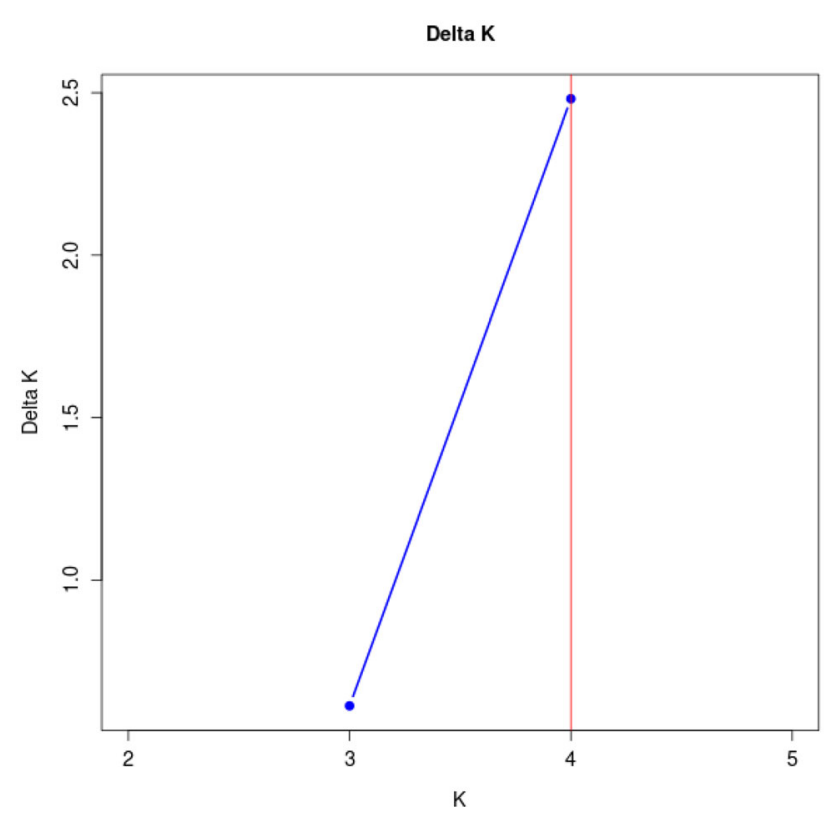

Fig. 4 Estimated number of clusters of Anagallis L. genotypes obtained for $\mathrm{K}=2-5$ based on $\Delta \mathrm{K}$
Gladiolus palustris, found that although most of the population of $G$. palustris in the regions retained significant genetic variation, genetic diversity is likely to decrease in small populations due to genetic drift.

UPGMA analyses grouped A. foemina samples into 2 clearly separated clusters based on places of their origin, with $A$. arvensis on the edge of dendrogram. PCoA results confirmed the clustering analyses. However the genetic similarity between $A$. foemina populations from Volhynian Polesie and West Volhynian Upland was even lower than genetic similarity of West Volhynian Upland samples to $A$. arvensis. It can indicate that genetic diversity of endangered A. foemina species is high and artificial crossing or introduction plants from isolated geographically regions can strengthen the probability of species survival.

A low level of genetic diversity is usually found in small, isolated populations (Jacquemyn et al. 2010; Crichton et al. 2016; Sullivan et al. 2019). The loss of species biodiversity in a given area is one of the main environmental problems (Godefroid et al. 2011; Brütting 2013). This also applies to species that currently survive in

Fig. 5 The graphic representation of Anagallis L. genotypes structure for $\mathrm{K}=2-5$. Different colours represent diverse genetic backgrounds. 1-9 VU1-VU9. 10-14 VP1-VP5. 15 VP/5_r (color figure online)

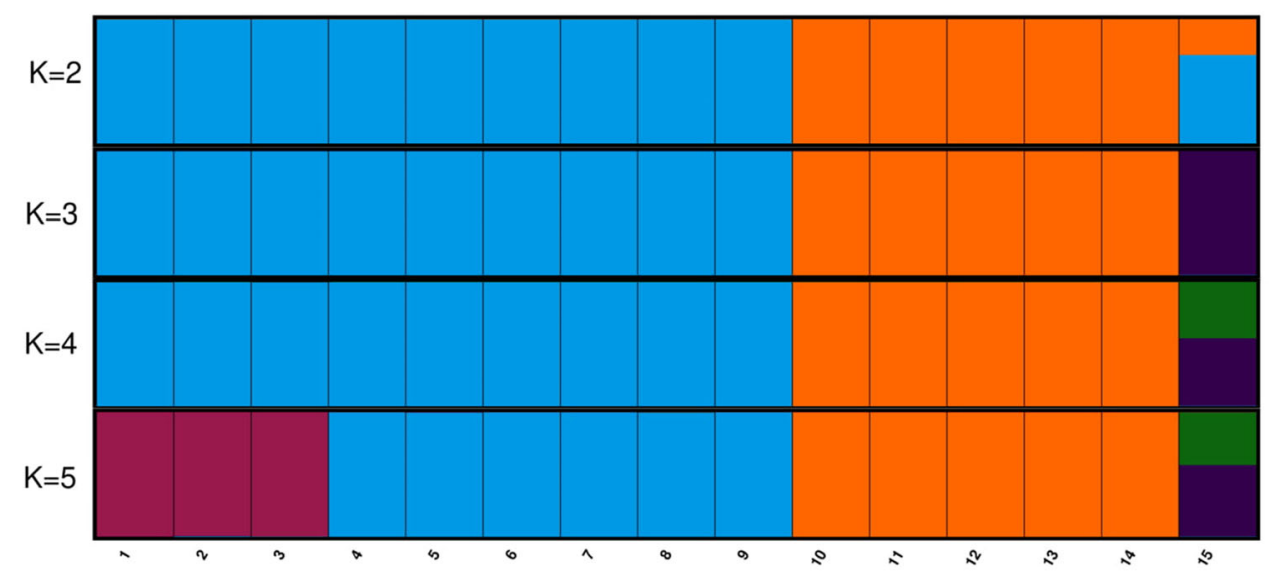


small quantities as a result of intensified agriculture (Honnay and Jacquemyn 2007). Such populations are more susceptible to genetic drift and reduced gene flow between populations (Ellstrand and Elam 1993; Sullivan et al. 2019).

More and more species are threatened, including agricultural weeds. Isolation of a small population leads to a decrease in internal genetic variation, which in turn contributes to a decrease in immunity and adaptability to environmental changes, a decrease in reproduction rate and increased mortality. As a consequence of fragmentation, genetic differentiation among populations and the loss of genetic diversity is expected to increase with time. This becomes the reason for the extinction of the local plants populations (Zawko et al. 2001). Hence, assessing the genetic diversity of plants, especially those rare and endangered is so important. A comprehensive approach, including the analysis of anthropogenic and habitat impacts, allows determining the species susceptibility to population reduction and developing strategies for its protection. According to Daco et al. (2019), in the case of high fragmentation of the population, in order to preserve biodiversity, the conservation of populations from each regional cluster is essential.

Open Access This article is licensed under a Creative Commons Attribution 4.0 International License, which permits use, sharing, adaptation, distribution and reproduction in any medium or format, as long as you give appropriate credit to the original author(s) and the source, provide a link to the Creative Commons licence, and indicate if changes were made. The images or other third party material in this article are included in the article's Creative Commons licence, unless indicated otherwise in a credit line to the material. If material is not included in the article's Creative Commons licence and your intended use is not permitted by statutory regulation or exceeds the permitted use, you will need to obtain permission directly from the copyright holder. To view a copy of this licence, visit http://creativecommons. org/licenses/by/4.0/.

\section{References}

Anderberg AA, Ståhl B (1995) Phylogenetic interrelationships in the order Primulales with special emphasis on the family circumscriptions. Can J Bot 73:1699-1730

Baessler C, Klotz S (2006) Effects of changes in agricultural land-use on landscape structure and arable weed vegetation over the last 50 years. Agric Ecosyst Environ 115:43-50

Banfi E, Galasso G, Soldano A (2005) Notes on systematics and taxonomy for the Italian vascular flora 1. Atti della Societa italiana di scienze naturalie del Museo civico di storia naturale di Milano 146:219-244

Brütting C (2013) Genetic diversity and population structure of arable plants in situ and ex situ-How sustainable is long term cultivation in botanical gardens compared to in situ conditions? Ph.D. dissertation, University Halle-Wittenberg Germany

Brütting C, Meyer S, Kühne P, Hensen I, Wesche K (2012a) Spatial genetic structure and low diversity of the rare arable plant
Bupleurum rotundifolium L. indicate fragmentation in central Europe. Agric Ecosyst Environ 161:70-77

Brütting C, Wesche K, Meyer S, Hensen I (2012) Genetic diversity of six arable plants in relation to their Red List status. Biodivers Conserv 3

Brütting C, Hensen I, Wesche K (2013) Ex situ cultivation affects genetic structure and diversity in arable plants. Plant Biol 15:505-513. https://doi.org/10.1111/plb201315issue-3

China Phylogeny Consortium (2016) Tree of life for the genera of Chinese vascular plants. J Syst Evol 54(4):277-306. https://doi. org/10.1111/jse12219

Clapham AR, Tutin TG, Moore DM (1987) Flora of the British Isles, 3rd edn. Cambridge University Press, Cambridge

Crichton RJ, Dalrymple SE, Woodin SJ, Hollingsworth PM (2016) Conservation genetics of the annual hemiparasitic plant $M e$ lampyrum sylvaticum (Orobanchaceae) in the UK and Scandinavia. Conserv Genet 17:547-556. https://doi.org/10.1007/ s1059.2-015-0803-4

Cwener A, Michalczuk W, Krawczyk R (2016) Red list of vascular plants of the Lublin Region. Annales UMCS 71(1):7-26

Daco L, Tiphaine M, Muller S, Rossa J, Colling G (2019) Genetic status of the endangered plant species Gladiolus palustris in the western part of its distribution area. Conserv Genet 20:1339-1354. https://doi.org/10.1007/s10592-019-01213-0

Dice LR (1945) Measures of the amount of ecologic association between species. Ecology 26:297-302. https://doi.org/10.2307/ 1932409

Fijałkowski D (1978) Plant synanthropes of the Lublin region. PWN Warsaw Poland

Frankham R (2010) Challenges and opportunities of genetic approaches to biological conservation. Biol Conserv 143:1919-1927

Frankham R, Ballou JD, Briscoe DA (2002) Introduction to conservation genetics. Cambridge University Press

Godefroid S, Rivie're S, Waldren S, Boretos N, Eastwood R, Vanderborght $\mathrm{T}$ (2011) To what extent are threatened European plant species conserved in seed banks? Biol Conserv 144:1494-1498

Haliniarz M, Kapeluszny J (2014) Rare species of calciphil flora in segetal communities in the Lubelskie Voivodeship. Annales UMCS 69(1):11-23

Hammer Ø, Harper DAT, Ryan PD (2001) PAST: paleontological Statistics Software Package for education and data analysis. Palaeontol Electron 4:1-9

Honnay O, Jacquemyn H (2007) Susceptibility of common and rare plant species to the genetic consequences of habitat fragmentation. Conserv Biol 21(3):823-831. https://doi.org/10.1111/j15231739200600646.x

Hu CM (1994) On the geographical distribution of the Primulaceae. J Trop Subtrop Bot 2:1-14

Jacquemyn H, Roldán-Ruiz I, Honnay O (2010) Evidence for demographic bottlenecks and limited gene flow leading to low genetic diversity in a rare thistle. Conserv Genet 11:1979-1987. https://doi.org/10.1007/s1059.2-010-0089-5

Janiak A, Galej K, Parusel JB, Szarejko I (2014) A study of the genetic variation of the aquatic fern Marsilea quadrifolia $\mathrm{L}$. preserved in botanical collections in Poland and originated from natural populations in Europe. Flora (Jena) 209:655-665

Källersjö M, Bergqvist G, Anderberg AA (2000) Generic realignment in primuloid families of the Ericales sl: a phylogenetic analysis based on DNA sequences from three chloroplast genes and morphology. Am J Bot 87(9):1325-1341. https://doi.org/10. $2307 / 2656725$

Kaźmierczakowa R, Bloch-Orłowska J, Celka Z, Cwener A, Dajdok Z, Michalska-Hejduk D, Pawlikowski P, Szczęśniak E, Ziarnek 
K (2016) Polish red list of pteridophytes and flowering plants. PAS Cracow

Kolárová M, Tyšer L, Soukup J (2013) Impact of site conditions and farming practices on the occurrence of rare and endangered weeds on arable land in the Czech Republic. Weed Res 53:489-498

Kopelman NM, Mayzel J, Jakobsson M, Rosenberg NA, Mayrose I (2015) Clumpak: a program for identifying clustering modes and packaging population structure inferences across K. Mol Ecol Resour 15:1179-1191. https://doi.org/10.1111/1755-099812387

Kornaś J (1962) Genus Anagallis L. in Poland. Fragmenta Flor Geobot 8:131-138

Kucharczyk M (2004) List of endangered and threatened species of vascular flora of the Lubelskie Voivodeship. Dissertation Univ of Life Sc. Lublin, Poland

Li YL, Liu JX (2018) StructureSelector: a web-based software to select and visualize the optimal number of clusters using multiple methods. Mol Ecol Resour 18:176-177. https://doi. org/10.1111/1755-099812719

Manns U, Anderberg AA (2005) Molecular phylogeny of Anagallis (Myrsinaceae) based on ITS trnL-F and ndhF sequence data. Int J Plant Sci 166:1019-1028

Manns U, Anderberg AA (2007a) Character evolution in Anagallis (Myrsinaceae) inferred from morphological and molecular data. Syst Bot 32(1):166-179

Manns U, Anderberg AA (2007b) Relationships of Anagallis foemina and $A$ arvensis (Myrsinaceae): new insights inferred from DNA sequence data. Mol Phylogenetics Evol 45:971-980

Manns U, Anderberg AA (2009) New combinations and names in Lysimachia (Myrsinaceae) for species of Anagallis, Pelletiera and Trientalis. Willdenowia 39:49-54

Mayerová M, Mikulka J, Soukup J (2018) Effects of selective herbicide treatment on weed community in cereal crop rotation. Plant Soil Environ 64(9):413-420

Meyer S, Wesche K, Krause B, Leuschner C (2013) Dramatic losses of specialist arable plants in Central Germany since the 1950s/ 1960s - a cross-regional analysis. Divers Distrib 19:1175-1187

Nei M, Li WH (1979) Mathematical model for studying genetic variation in terms of restriction endonucleases. Proc Natl Acad Sci USA 76:5269-5273

Nowak A, Nowak S, Spałek K (2008) Red list of vascular plants of Opole province-2008. Nat J 41:141-158

Parusel JB, Bączkiewicz A, Buczkowska K (2009) Genetic structure of the population of the mountain abacus Streptopus amplexifolius (L.) DC in the nature reserve "Ochojec" in Katowice (Silesian Upland Upper Silesia) 269-284. In: Parusel JB (ed) The nature reserve Ochojec in Katowice (Upper Silesia) Scientific monograph. Didactic Center of the Natural Heritage of Upper Silesia Katowice Poland

Pax F, Knuth R (1905) Primulaceae. Verlag von Wilhelm Engelmann, Leipzig

Peakall R, Smouse PE (2012) GenAlEx 65: genetic analysis in Excel Population genetic software for teaching and research-an update. Bioinformatics 28:2537-2539. https://doi.org/10.1093/ bioinformatics/bts460

Pejic IP, Ajmone-Marsan M, Morgante V, Kozumplicck P, Castiglioni G, Taramino M, Motto M (1998) Comparative analysis of genetic similarity among maize inbred lines detected by RFLPs RAPDs SSRs and AFLPs. Theor Appl Genet 97:1248-1255

Porras-Hurtado L, Ruiz Y, Santos C, Phillips C, Carracedo A, Lareu MV (2013) An overview of STRUCTURE: applications parameter settings and supporting software. Front Genet 4:98. https:// doi.org/10.3389/fgene201300098

Roldán-Ruiz I, Calsyn E, Gilliland TJ, Coll R, Van Eijk MJT, De Loose M (2000a) Estimating genetic conformity between related ryegrass (Lolium) varieties 2 AFLP characterization. Mol Breed 6:593-602

Roldán-Ruiz I, Dendauw J, Van Bockstaele E, Depicker A, De Loose M (2000b) AFLP markers reveal high polymorphic rates in ryegrasses (Lolium spp.). Mol Breed 6:125-134

Rutkowski L (2006) Key for the determination of lowland Poland vascular plants. PWN Warsaw 814

Siciński J, Sieradzki J (2010) Protection of segetal flora and vegetation in Poland. Plant Breed Seed Sci 61(1):123-131

Smouse PE, Long JC, Sokal RR (1986) Multiple regression and correlation extensions of the Mantel test of matrix correspondence. Syst Zool 35(4):627-632. https://doi.org/10.2307/ 2413122

Stahl B, Anderberg AA (2004) Myrsinaceae. In: Kubitzki K (ed) The families and genera of vascular plants, vol 6. Springer, Heidelberg, pp 266-281

Staniak M, Haliniarz M, Kwiecińska-Poppe E, Harasim E, Wesołowski M (2017) Diversity of agrocoenoses in the Lublin region Poland. Acta Agrobot 70(4):1722. https://doi.org/10. 5586/aa1722

Storkey J, Meyer S, Still KS, Leuschner C (2012) The impact of agricultural intensification and land-use change on the European arable flora. Proc Roy Soc B 279:1421-1429

Sullivan ER, Barker C, Powell I, Ashton PA (2019) Genetic diversity and connectivity in fragmented populations of Rhinanthus minor in two regions with contrasting land-use. Biodiv Conserv 28:3159-3181

Yan HF, Zhang CY, Anderberg AA, Hao G, Ge XJ, Wiens JJ (2018) What explains high plant richness in East Asia? Time and diversification in the tribe Lysimachieae (Primulaceae). New Phytol 219:436-448. https://doi.org/10.1111/nph15144

Zawko G, Krauss SL, Dixon KW, Sivasithamparam K (2001) Conservation genetics of the rare and endangered Leucopogon obtectus (Ericaceae). Mol Ecol 10:2389-2396. https://doi.org/10. 1046/j0962-1083200101378.x

Zietkiewicz E, Rafalski A, Labuda D (1994) Genome fingerprinting by simple-sequence repeat (SSR)-anchored polymerase chain reaction amplification. Genomics 20:176-183

Publisher's Note Springer Nature remains neutral with regard to jurisdictional claims in published maps and institutional affiliations. 